\title{
EKLEKTISISME HUKUM PERIKATAN NASIONAL (POTENSI, KELEMAHAN, PELUANG, DAN ANCAMAN IMPLIKASINYA BAGI DINAMIKA EKONOMI SYARIAH DI INDONESIA)
}

\author{
Nurul Mahmudah \\ Institut Agama Islam Negeri (IAIN) Metro \\ Email: nurulmahmudah@metrouniv.ac.id \\ Muhammad Yusuf Putra \\ Universitas Negeri Gorontalo \\ Email: yusufmalika@gmail.com
}

\begin{abstract}
This paper discusses the existence of a sharia system in banking that collaborates with the conventional banking system that has long been implemented in Indonesia. In this collaboration, it is believed that it will create positive and negative effects on the regulatory side or its rationalization for the dynamics of Islamic Economics in Indonesia. This paper uses library research with a qualitative approach with a descriptive nature that tends to use analysis. In this approach, the subject's perspective is emphasized, namely the process and meaning of the research carried out. The results of this paper are that the legal eclecticism of national engagement here has potential advantages, weaknesses, opportunities and threats for the sharia system and conventional systems in banking itself. In the positive side, there are regulations and ease of access to favorable bank itself, while the negative can be seen from the decline in public confidence in the system of sharia in banking due to the mixing of the system both the system then the conventional banking and sharia considered only different in name only.
\end{abstract}

Keywords: Law National Association, Sharia Economics, Banking.

\section{A. Pendahuluan}

Lahirnya lembaga perbankan di Indonesia mempunyai manfaat yang luar biasa bagi kehidupan masyarakat. Selain sebagai tempat untuk menyimpan uang, lembaga perbankan juga dapat digunakan sebagai tempat investasi, serta sebagai solusi ketika membutuhkan dana pinjaman untuk sebuah usaha. Namun, pada prakteknya, peminjaman dana pada perbankan juga memunculkan bunga (interests) yang harus dibayarkan selain dari pinjaman pokok.

Istilah bunga bank ini kemudian memicu pro dan kontra, terutama di kalangan para aktivis Islam. Bunga bank dipandang sama seperti praktek riba yang diharamkan dalam Islam. Sehingga, dari sini kemudian muncul sebuah lembaga perbankan yang menerapkan prinsip-prinsip ekonomi Islam dan menggunakan system bagi hasil sebagai ganti dari system bunga.

Kehadiran perbankan syariah secara tidak langsung menghidupkan fiqh muamalat dalam realita, dari sini tercermin kepercayaan orang-orang terhadap fiqh muamalat dapat diterapkan pada zaman modern ini. Meskipun demikian, perubahan tersebut belum bisa dikatakan berjalan mulus dikarenakan oleh beberapa faktor, antara lain, masalah teknis, sumber daya manusia, serta keterbatasan pengetahuan orang tentang bank syariah.

Terlepas dari keunggulan dan kelemahan dari masing-masing system yang diterapkan dalam lembaga perbankan tersebut, dalam tulisan ini akan membahas tentang percampuran atau penggabungan dari system konvensional dan system 
syariah dalam lembaga perbankan. Dari percampuran system ini akan menimbulkan efek positif maupun negative sebagai konsekuensinya.

\section{B. Pembahasan}

\section{B.1. Eklektisisme Hukum Perikatan Nasional}

Dalam kamus Webster's, eklektisisme berasal dari Bahasa Yunani "eklekticoseklegein" yang artinya memilih. Eclectic artinya choosing, selecting from various systems, doctrine, or sources (pilihan dari berbagai system, doktrin, atau sumber). Eclecticism diartikan dengan the method or system of an eclectic (metode atau system untuk pilihan dari beberapa sumber). Sedangkan dalam Kamus Besar Bahasa Indonesia, eklektik diartikan dengan "bersifat memilih yang terbaik dari berbagai sumber". Sementara eklektisisme diartikan dengan "paham atau aliran filasafat yang mengambil yang terbaik". ${ }^{1}$ Lebih lanjut, eklektisime adalah sikap berfilsafat dengan mengambil teori yang sudah ada dan memilah mana yang disetujui dan mana yang tidak, sehingga dapat selaras dengan semua teori itu. Hal ini dilakukan agar dapat mengambil nilai yang berguna dan dapat diterima. ${ }^{2}$

Adapun yang dimaksud dengan eklektisisme hukum perikatan nasional dalam makalah ini adalah tercampurnya system syariah dan konvensional dalam sebuah bank. Di mana kita melihat terlebih dahulu potensi, keunggulan, kelemahan, dan juga ancaman dari masing-masing system, untuk kemudian di analisis bagaimana jika seandainya kedua system tersebut digabungkan dan diterapkan dalam sebuah lembaga perbankan.

\section{B.2. Perbankan Konvensional di Indonesia}

Sebagai lembaga keuangan yang berorientasi bisnis, bank juga melakukan berbagai kegiatan sehari-hari yang tidak terlepas dari bidang keuangan. Kegiatan perbankan yang paling pokok adalah membeli uang dengan cara menghimpun dana dari masyarakat luas. Kemudian menjual uang yang berhasil dihimpun dengan cara menyalurkan kembali kepada masyarakat melalui pemberian pinjaman.

Dari kegiatan jual beli uang inilah bank akan memperoleh keuntungan yaitu dari selisih harga beli (bunga simpanan) dengan harga jual (bunga pinjaman). Di samping itu, kegiatan bank lainnya dalam rangka mendukung kegiatan menghimpun (funding) dan menyalurkan dana (lending) adalah memberikan jasajasa lainnya (services). Kegiatan-kegiatan ini ditujukan untuk memperlancar kegiatan menghimpun dan menyalurkan dana. ${ }^{3}$

Kegiatan menghimpun dana (funding) terdiri dari, simpanan giro (demand deposit), simpanan tabungan (saving deposit), simpanan deposito (time deposit). Sedangkan kegiatan menyalurkan dana (lending) terdiri dari, kredit investasi, kredit modal kerja, kredit perdagangan, kredit produktifk kredit konsumtif, kredit profesi. Sementara layanan jasa-jasa lainnya yaitu seperti jasa kiriman uang (transfer), kartu kredit, dan lain sebagainya. Adapun Potensi atau Keunggulan Perbankan Kenvensional di Indonesia adalah sebagai berikut:

${ }^{1}$ Qodri Azizy, Hukum Nasional: Eklektisisme Hukum Islam dan Hukum Umum, (Jakarta: TERAJU, 2004), h. 12.

2 Wikipedia: Ensiklopedia Bebas, Eklektisisme, dalam https://id.m.wikipedia.org/wiki/Eklektisisme, diakses pada tanggal 3 Mei 2016.

${ }^{3}$ Kasmir, Dasar-Dasar Perbankan, (Jakarta: PT Raja Grafindo Persada, 2006), h. 29. 
1. Sudah lama berdiri, sehingga dikenal masyarakat.

2. Peraturan perundang-undangan dan kebijakan pemerintah yang lebih mapan bagi bank konvensional, sehingga bank lebih leluasa untuk bergerak lebih pasti.

3. Jaringan yang luas dan maju, didukung dengan promosi di media massa sehingga mudah dikenal masyarakat.

4. Membantu usaha nasabah, yaitu dengan cara memberikan dana kepada nasabah yang memerlukan dana, baik dana untuk investasi maupun dana untuk modal kerja. Dengan demikian, debitur (nasabah) akan mampu mengembangkan dan memperluas usahanya.

5. Membantu pemerintah dalam berbagai bidang, karena bagi pemerintah semakin banyak kredit yang disalurkan oleh pihak perbankan, maka semakin baik, mengingat semakin banyak kredit berarti adanya kucuran dana dalam rangka peningkatan pembangunan di berbagai sektor, terutama sektor riil. Secara garis besar keuntungan pemerintah yaitu: ${ }^{4}$

a. Penerimaan pajak, dari keuntungan yang diperoleh nasabah dan bank.

b. Membuka kesempatan kerja, dalam hal kredit untuk pembangunan usaha baru atau perluasan usaha, maka akan membutuhkan tenaga kerja baru, sehingga membuka peluang bagi para pengangguran.

c. Meningkatkan jumlah barang dan jasa, karena dengan kredit tadi nasabah mendirikan atau memperluas usahanya, sehingga akan banyak barang-barang yang diproduksi dan diedarkan di masyarakat.

d. Menghemat devisa Negara, untuk produk yang sebelumnya diimpor dan akhirnya sudah dapat diproduksi di dalam negeri dengan fasilitas kredit yang ada, hal ini jelas menghemat devisa Negara.

e. Meningkatkan devisa Negara, apabila produk dari kredit yang dibiayai untuk keperluan ekspor.

Terdapat beberapa kelemahan dalam system perbankan konvensional yang berbasis bunga, diantaranya yaitu:

1. Transaksi berbasis bunga melanggar keadilan atau kewajaran bisnis, di mana bank tidak memperdulikan apakah peminjam untung atau rugi, yang pasti peminjam harus mengembalikan pokok pinjaman beserta bunganya kepada bank.

2. Tidak fleksibelnya sistem transaksi berbasis bunga menyebabkan kebangkrutan.

3. Komitmen bank untuk keamanan uang deposan berikut bunganya membuat bank cemas untuk mengembalikan pokok dan bunganya. Oleh karena itu, demi keamanan, bank hanya mau meminjamkan dana bagi usaha atau bisnis yang telah mapan.

4. Sistem transaksi berbasis bunga menghalangi inovasi oleh usaha kecil, karena para pengusaha kecil tidak dapat mencoba ide (usaha) barunya tanpa meminjam dana ke bank yang harus difikirkan pengembalian pokok pinjaman beserta bunganya dalam kedalan untung maupun rugi, di sisi lain, bank juga tidak mau memberikan pinjaman bagi usaha yang belum mapan.

5. Dalam sistem bunga, bank tidak akan tertarik dalam komitmen usaha, kecuali apabila ada jaminan kepastian pengembalian modal dan pendapatan

${ }^{4}$ Kasmir, Dasar-Dasar Perbankan..., h. 106. 
bunga mereka. Setiap rencana bisnis yang diajukan kepada bank, akan selalu diukur dengan kriteria ini. ${ }^{5}$

Namun tidak menutup kemungkinan bahwa Peluang Perbankan Konvensional di Indonesia begitu besar antara lain Dengan adanya peraturan peraundang-undangan yang memadai dan melindungi perbankan konvensional, membuatnya dapat bergerak lebih leluasa dalam menjalankan usahanya. Misalnya dengan membuat produk-produk baru atau memperluas jaringannya, berupa mendirikan cabang-cabang kantornya, dan lain sebagainya. Kemudian Keberadaan bank konvensional yang telah berdiri sejak lama membuatnya dikenal masyarakat, sehingga dapat dengan mudah menarik simpati serta kepercayaan masyarakat untuk menggunakan jasa perbankan konvensional.

\section{B.3. Ancaman Perbankan Konvensional di Indonesia}

Apabila kita melihat ke belakang, yaitu tahun 1997 ketika krisis ekonomi melanda negara-negara Asia termasuk Indonesia. Peristiwa ini sekaligus membuktikan tentang betapa besar efek negative yang ditimbulkan oleh sistem bunga yang diterapkan pada bank konvensional terhadap inflasi, investasi, produksi, pengangguran, dan kemiskinan hingga memporak-porandakan hampir semua aspek sendi kehidupan ekonomi dan social politik Indonesia.

Selanjutnya, dalam sistem perbankan konvensional, bank selain berperan sebagai jembatan antara pemilik dana dan dunia usaha, juga masih menjadi penyekat antara keduanya karena tidak adanya transferability risk dan return. ${ }^{6}$ Transferability risk adalah konsep asuransi konvensional di mana perusahaan menerima premi dari peserta sebagai kompensasi atas pengalihan resiko kepadanya. Artinya, premi tersebut diakui sebagai milik perusahaan sepenuhnya, apabila terjadi klaim maka perusahaan akan membayarkan sejumlah uang pertanggungan. Namun, apabila tidak terjadi klaim, peserta asuransi tidak akan mendapatkan apapun atau dananya hangus, manfaat yang dapat dirasakan hanya rasa aman.

Sedangkan dalam asuransi syariah dikenal dengan risk sharing, di mana antar peserta asuransi saling tolong menolong untuk membagi resiko yang akan dihadapi dengan mengumpulkan sejumlah premi yang di dalamnya terdapat dana tabarru'. Perusahaan asuransi hanya bertugas sebagai wakil untuk mengelola dana peserta tersebut, namun dia mendapatkan ujrah atas jasanya dan bagi hasil dari investasi dana tabarru' tersebut. ${ }^{7}$

\section{B.4. Perbankan Syariah di Indonesia}

Apabila kita melihat wajah perbankan Indonesia saat ini, akan nampak perbedaannya dengan perbankan zaman dahulu, baik dari keanekaragaman produk yang ditawarkan, maupun dari sistem yang digunakan. Keanekaragaman produk itu seperti, electronic banking, internet banking, home banking, dan lain sebagainya. Selain munculnya produk-produk tersebut, di akhir abad 20 ini,

${ }^{5}$ Amir Machmud dan Rukmana, Bank Syariah: Teori, Kebijakan, dan Studi Empiris di Indonesia, (Jakarta: Erlangga, 2010), h. 5.

${ }^{6}$ Amir Machmud dan Rukmana, Bank Syariah..., h. 6.

7 Eka Widia, Risk Sharing os Risk Transfer, dalam http://sebishariainsurance.blogspot.co.id/2013/04/risk-sharing-vs-risk-transfer_26.html?m=1, diakses pada tanggal 6 Mei 2016. 
perbankan nasional semakin marak dengan lahirnya perbankan syariah yang menggunakan system baru yang sebelumnya tidak dikenal.

Alasan mendasar lahirnya bank syariah sebenarnya lebih berkaitan dengan masalah keyakinan berupa unsur riba (bunga), ketidak adilan dan moralitas dalam melakukan usaha. Penerapan bunga sebagai landasan operasional perbankan yang ada sebelumnya (konvensional) dianggap sebagai bentuk transaksi riba yang dalam agama Islam jelas diharamkan. Bunga (interests) diyakini mengandung unsur riba karena dalam system bunga tersebut terdapat unsur ketidak adilan karena pemilik dana mewajibkan peminjam dana untuk membayar lebih dari pada yang dipinjam tanpa memperhatikan apakah peminjam mengalami keuntungan atau kerugian.

Sementara itu, bank syariah lahir dengan prinsip-prinsip syariah Islam yang diterapkan dalam produk dan jasa-jasa yang ditawarkan. Prinsip-prinsip dasar dari produk dan jasa perbankan syariah antara lain, yaitu prinsip titipan (wadi'ah), prinsip bagi hasil (profit sharing), prinsip jual beli (bai' atau tijarah), prinsip sewa (ijarah), prinsip jasa (fee-based service). ${ }^{8}$

\section{B.5. Potensi atau Keunggulan Perbankan Syariah di Indonesia}

Perbankan syariah merupakan salah satu bentuk institusi perekonomian Islam. Dalam menawarkan jasanya, perbankan syariah dilandasi oleh prinsipprinsip ekonomi Islam yang berpegang pada nilai-nilai keadilan. Di antara beberapa keunggulan perbankan syariah adalah:

1. Perbankan syariah menerapkan prinsip-prinsip ekonomi Islam, di mana ekonomi dan etika digabungkan. Di samping mampu memberikan nilai tambah pada sistem, etika juga dapat mengisi kekosongan pemikiran yang ditakutkan suatu saat timbul akibat perkembangan teknologi. Sebagaimana yang terjadi pada sistem ekonomi saat ini yang terlalu dikuasai oleh nafsu kapitalis di atas norma-norma yang hakiki. Sementara perbankan syariah, dengan system ekonomi Islamnya, memasukkan nilai etika ke dalam ekonomi. ${ }^{9}$

2. Selain menawarkan produk jasa yang umum diberikan oleh perbankan konvensional (commercial bank), juga menawarkan jasa yang ditawarkan oleh lembaga pembiayaan konvensional (multi finance company).

3. Hubungan antara bank sebagai pemberi jasa dan nasabah juga berlandaskan pada perlindungan yang seimbang terhadap kepentingan kedua belah pihak, baik pihak bank maupun pihak nasabah.

4. Adanya fungsi charity ( $\left.t a^{\prime} a w u n\right)$, hal ini berbeda dengan bank konvensional, bank syariah memberikan fasilitas pembiayaan yang disebut dengan alQardh al-hasan (benevolent loan). ${ }^{10}$

5. Bebas dari bunga (interests atau riba), yaitu tambahan atau premi yang harus dibayar oleh debitur pada kreditur di samping pengembalian pokok, yang ditetapkan sebelumnya atas setiap jenis pinjaman.

6. Bebas dari kegiatan spekulatif non produktif.

8 M. Sulhan dan Ely Siswanto, Manajemen Bank Konvensional dan Syariah, (Malang: UIN Malang Press, 2008), h. 131.

9 Yusuf Qardhawi, Norma dan Etika Ekonomi Islam, (Jakarta: Gema Insani Press, 1997), h. 55.

${ }_{10}$ Neni Sri Imaniyati, Hukum Ekonomi dan Ekonomi Islam, (Bandung: Mandar Maju, 2002), h.

75. 
7. Bebas dari hal-hal yang meragukan (gharar).

8. Hanya membiayai kegiatan yang halal, usaha dalam prinsip syariah hanya diperbolehkan pada usaha-usaha yang tidak diragukan kehalalannya baik secara formal maupun substansial, misalnya melakukan jual beli barang curian dan lain-lain. ${ }^{11}$

9. Penerapan sistem bagi hasil dan ditinggalkannya sistem bunga menjadikan bank Islam lebih mandiri dari pengaruh gejolak moneter baik dari dalam maupun dari luar negeri.

Adapun beberapa Kelemahan Perbankan Syariah di Indonesia antara lain

1. Masalah hukum atas operasional bank syariah

a. Perpajakan

Masalah ini timbul disebabkan oleh bank syariah selain menggunakan prinsip bagi hasil, juga menggunakan prinsip jual beli (bai') dan prinsip sewa (ijarah). Akad pembiayaan jual beli memberikan konsekuensi pajak atas jual beli, maka akan menimbulkan double taxation, yaitu pajak yang timbul pada saat bank melakukan pembelian dan pajak atas penjualan yang dilakukan oleh bank kepada nasabah. Di samping pajak penghasilan, akibatnya beban yang ditanggung nasabah bank syariah akan menjadi lebih tinggi dibanding bank konvensional.

Selain itu, bank syariah juga menyediakan akad pembiayaan yang dapat dipersepsikan sebagai akad pinjam meminjam (qardh alhasan). Dalam akad ini, bank syariah sama sekali tidak boleh memungut biaya dari penerima qardh kecuali biaya administrasi. Namun, akad ini akan terkena pajak, sehingga pajak ini akan dikenakan oleh bank kepada penerima qardh.12

Qardh al-hasan merupakan kegiatan penyaluran dana dalam bentuk pinjaman kebajikan tanpa imbalan dengan kewajiban pihak peminjam mengembalikan pokok pinjaman secara sekaligus atau cicilan dalam jangka waktu tertentu. Dalam peraturannya, bank hanya diperbolehkan membebankan biaya administrasi dengan nominal tertentu, tanpa terkait dengan jumlah dan jangka waktu pinjaman. Namun, dalam peraturan lain-lain juga disebutkan bahwa, semua biaya administrasi yang timbul akibat dari perjanjian ini dapat ditanggung oleh nasabah (penerima pinjaman). Mungkin atas dasar inilah, pajak yang ditimbulkan dari perjanjian qardh al-hasan ini oleh pihak bank dihitung sebagai biaya administrasi, sehingga ditanggung oleh nasabah tersebut. Hal ini sejalan dengan perkembangan dunia ekonomi keuangan dan perbankan, qardh al-hasan tidak mungkin dapat dilaksanakan tanpa adanya biaya materai, notaris, peninjauan feasibility proyek, biaya pegawai bank dan lain-lain, sehingga pengenaan biaya-biaya administrasi tersebut tidak dapat dihindari. ${ }^{13}$

11 M. Sulhan dan Ely Siswanto, Manajemen Bank Konvensional dan Syariah, (Malang: UIN Malang Press, 2008), h. 128.

12 Neni Sri Imaniyati, Hukum Ekonomi dan..., h. 83.

${ }^{13}$ Muhammad, Sistem dan Prosedur Operasional Bank Syariah, (Yogyakarta: UII Press, 2000), h. 151. 


\section{b. Manajemen Sumber Daya Manusia}

Kendala di bidang sumber daya manusia dalam pengembangan perbankan syariah disebabkan karena system ini masih belum lama dikembangkan. Di samping itu, lembaga-lembaga akademik dan pelatihan di bidang ini sangat terbatas sehingga tenaga terdidik dan berpengalaman di bidang perbankan syariah, baik dari sisi pelaksana maupun dari bank sentral (pengawas dan peneliti bank) masih sangat sedikit. Pengembangan sumber daya manusia di bidang perbankan syariah sangat diperlukan, karena keberhasilan pengembangan bank syariah pada level mikro sangat ditentukan oleh kualitas manajemen dan tingkat pengetahuan serta ketrampilan pengelola bank.

Sumber daya manusia dalam perbankan syariah harus memiliki pengetahuan yang luas di bidang perbankan, memahami implementasi prinsip-prinsip syariah dalam praktik perbankan, serta mempunyai komitmen kuat untuk menerapkannya secara konsisten. Dalam hal pengembangan bank syariah atau membuka kantor cabang syariah oleh bank umum konvensional, permasalahan ini mejadi lebih penting, karena diperlukan suatu perubahan pola pikir dari system usaha bank yang beroperasi secara konvensional ke bank yang beroperasi dengan prinsip syariah. ${ }^{14}$

Fenomena yang ada saat ini, banyak ditemukan pegawai perbankan syariah yang bukan berasal dari lulusan perguruan tinggi Islam ataupun mereka yang memiliki background program studi perbankan syariah. Adanya fenomena ini dapat disebabkan oleh dua hal, yang pertama, minimnya perguruan tinggi yang menyediakan program studi tentang ekonomi Islam khususnya perbankan syariah. Dan yang kedua, kualitas dari lulusan program studi ekonomi Islam tersebut dianggap kurang kompeten sehingga tidak siap bersaing dengan lulusan ekonomi secara umum. ${ }^{15}$

Apabila kita melihat fenomena yang terjadi di berbagai perguruan tinggi, baik umum maupun Islam, sudah banyak yang membuka program studi ekonomi Islam. Dengan demikian, tinggal bagaimana peran perguruan tinggi tersebut bekerja sama dengan pemerintah untuk meningkatkan kualitas lulusannya melalui standar kurikulum atau pendidikan serta pelatihan-pelatihan yang berbasis ekonomi Islam, khususnya tentang perbankan syariah. Selanjutnya, masing-masing individu dari lulusan program studi ekonomi Islam juga harus meningkatkan kualitas dirinya agar mampu bersaing dengan lulusan program studi ekonomi maupun perbankan secara umum. Dengan demikian, mereka dapat mengisi posisi sumber daya manusia yang ada pada perbankan syariah, yang sebelumnya diisi oleh mereka-mereka yang tidak mempunyai background ekonomi Islam.

14 Muhammad Syafi'I Antonio, Bank Syariah dari Teori ke Praktek, (Jakarta: Gema Insani Press, 2001), h. 226.

15 Abdur Rahman Adi Saputera, "Penyelesaian Sengketa Ekonomi Syariah di Indonesia," Nizham Journal of Islamic Studies, Vol.7, No.01, Juli 2019 h. 131-48. 
2. Produk bank syariah: Murabahah

Konsep ideal perbankan yang sesuai dengan syariah Islam seperti mudharabah dan musyarakah, pada praktikknya belum diselenggarakan secara ideal oleh bank-bank syariah di Indonesia. Mereka lebih banyak mempraktekkan murabahah karena dinilai lebih kecil resikonya dan lebih mudah dalam administrasinya. Murabahah dalam perbankan adalah akad jual beli barang, sebesar harga pokok barang ditambah dengan margin keuntungan yang disepakati. Bank harus tetap memberitahukan kepada nasabah tentang harga beli awal dari barang tersebut, kemudian baru disepakati berapa keuntungan yang akan didapat bank dari menjual barang tersebut kepada nasabah. Jadi, di sini bank mendapat keuntungan dari menjual barang tersebut kepada nasabah. Namun, semua biaya administrasi yang timbul akibat perjanjian ini ditanggung oleh nasabah dan diakui sebagai pendapatan bank. Biaya tersebut berupa biaya admnistrasi dan biaya lainnya, seperti biaya notaris, asuransi, dan lain sebagainya. ${ }^{16}$

Menurut Zainul Arifin, beberapa praktik perbankan syariah yang masih jauh dari konsep ideal bank syariah adalah:17

a. Terlalu memusatkan pada mekanisme murabahah dan mengabaikan mekanisme pembiayaan sah lainnya.

b. Menerapkan tingkat bunga untuk margin keuntungan tetap dalam mekanisme murabahah.

c. Mengabaikan aspek-aspek sosial dalam pembiayaan

d. Bank syariah belum menjadi partner usaha dalam lingkup yang luas dan terintegrasi, karena di samping menyediakan modal yang dibutuhkan oleh pengusaha kecil menengah, idealnya bank syariah juga harus memberikan pendampingan manajerial, seperti aspek pemasaran keuangan dan produksi bahkan sampai memfasilitasi jaringan pemasaran (tata niaga) yang lebih efisien dan menguntungkan.

3. Jaringan kantor bank syariah yang belum luas

Pengembangan jaringan kantor bank syariah diperlukan dalam rangka perluasan jangkauan pelayanan kepada masyarakat. Di samping itu, kurangnya jumlah bank syariah yang ada juga menghambat perkembangan kerjasama antar bank syariah. Sebagai suatu badan usaha, bank syariah perlu beroperasi dengan skala yang ekonomis, oleh karena itu jumlah jaringan kantor bank yang luas juga akan meningkatkan efisiensi usaha. Berkembangnya jaringan bank syariah juga diharapkan dapat meningkatkan kompetisi ke arah peningkatan kualitas dan mendorong inovasi produk dan jasa perbankan syariah.

\section{B.5. Peluang Perbankan Syariah di Indonesia}

Fenomena yang terjadi pada dunia perbankan akhir-akhir ini yaitu munculnya perbankan yang berlandaskan syariah sebagai dinamika perkembangan perbankan konvensional, dapat kita lihat secara jelas. Di Indonesia, sebagai gebrakan awal, lahirlah Bank Muamalat Indonesia, dan harus

16 Muhammad, Sistem dan Prosedur..., h. 110.

17 Amir Machmud dan Rukmana, Bank Syariah..., h. 29. 
diakui pertumbuhan bank syariah di Negara ini merupakan fenomena yang cukup menarik.

Peluang bank syariah cukup besar, dapat kita lihat dari sisi peluang pasar yang sangat potensial dan menggiurkan dari segi profitabilitasnya yaitu jumlah penduduk Indonesia yang terus meningkat. Selain itu, tingginya profitabilitas bank syariah tercermin dari banyaknya pelaku perbankan asing yang ikut andil dalam membuka unit bank yang berlandaskan syariah dan menerima keuntungan yang tidak sedikit, seperti HSBC, Citibank, dan ABN Amro.

Di sisi lain, bank syariah dengan system bagi hasilnya telah berhasil selamat dan berdiri kokoh serta tidak terpengaruh oleh krisis moneter yang terjadi pada tahun 1997. Di mana return yang diberikan oleh bank syariah kepada nasabah pemilik dana pun ternyata lebih tinggi dari pada bunga deposito yang diberikan oleh bank konvensional. ${ }^{18}$

Selain beberapa kelemahan dari perbankan syariah yang telah disebutkan sebelumnya, terdapat faktor lain yang juga mengancam perkembangan perbankan syariah itu sendiri, diantaranya yaitu:

1. Konsep-konsep ideal dalam perbankan syariah tidak diimbangi dengan praktek yang sesuai di lapangan, sebagaimana praktek murabahah yang diterapkan dalam perbankan syariah. Kalangan perbankan syariah di Indonesia banyak menggunakan murabahah secara berkelanjutan (roll over atau evergreen) seperti untuk modal kerja. Padahal sebenarnya, murabahah adalah kontrak jangka pendek dengan sekali akad (one short deal) yang tidak tepat apabila diterapkan untuk skema modal kerja. Akad mudharabah lebih sesuai untuk skema tersebut, mengingat prinsip mudharabah yang memiliki fleksibilitas yang sangat tinggi. Murabahah memang memberi manfaat kepada bank syariah, salah satunya yaitu adanya keuntungan yang muncul dari selisih harga beli dari penjual dengan harga jual kepada nasabah. Selain itu sistem ini juga sangat sederhana, sehingga memudahkan penanganan administrasinya di bank syariah. Akan tetapi, terdapat beberapa kemungkinan resiko yang harus diantisipasi oleh pihak bank agar terhindar dari kerugian, diantaranya yaitu: ${ }^{19}$

a. Default atau kelalaian, nasabah sengaja tidak membayar angsuran.

b. Fluktuasi harga komparatif, terjadi apabila harga suatu barang di pasar naik setelah bank membelikannya untuk nasabah, bank tidak bisa mengubah harga jual beli tersebut.

c. Penolakan nasabah dengan berabgai sebab, barang rusak di perjalanan sehingga nasabah tidak mau menerima, atau barang tidak sesuai dengan spesifikasi pesanan nasabah. Sementara bank telah menandatangani kontrak pembelian dengan penjualnya, dan barang itu menjadi milik bank, sehingga bank mempunyai resiko untuk menjualnya kepada pihak lain.

d. Dijual oleh nasabah, karena ketika nasabah sudah menandatangani kontrak jual beli dengan bank, maka barang itu menjadi hak milik nasabah, dan nasabah bebas melakukan apapun terhadap barang miliknya, termasuk menjualnya. Jika hal ini terjadi, resiko untuk default sangat besar.

18 Amir Machmud dan Rukmana, Bank Syariah..., h. 6.

${ }^{19}$ Muhammad Syafi'i Antonio, Bank Syariah dari..., h. 107. 
2. Pemahaman masyarakat yang belum tepat terhadap kegiatan operasional bank syariah. Dalam persepsi masyarakat, bank syariah mestilah bank yang paling ideal dan paling sempurna. Padahal, bank syariah bukanlah Islam, ia hanya sekedar bank yang berusaha menerapkan konsep syariah menurut kemampuan perkembangannya. Terdapat beberapa strategi yang dapat dilakukan untuk mengembangkan bank syariah dalam memberdayakan ekonomi umat, diantaranya yaitu:

a. Strategi pengembangan Islamic full branch, yaitu suatu cabang penuh yang menerapkan system syariah, pembukaannya terpisah dari kantor induk. Seperti BRI Syariah, Bank Syariah Mandiri.

b. Strategi pengelolaan pembiayaan, yaitu dengan menerapkan system bagi hasil karena dirasa lebih sesuai dengan pengusaha kecil. Bank syariah secara bertahap harus mengembangkan system pembiayaan mudharabah dan musyarakah agar portofolio pembiayaannya tidak terlalu didominasi oleh pembiayaan murabahah.

c. Strategi pengelolaan persepsi masyarakat, persepsi masyarakat tentang bank syariah masih keliru, mereka memandang bank syariah sebagai bank sosial untuk membantu pembangunan ekonomi umat, akibatnya masyarakat memahami bahwa bank syariah tidak boleh meminta jaminan dalam memberikan pembiayaan, tidak boleh mengenakan denda apabila nasabah tidak membayar tepat waktu, dan tidak boleh menyita jaminan. Kesalahan persepsi yang kedua, yaitu bank syariah dianggap sebagai bank bagi hasil, akibatnya mereka menginginkan untuk semua kebutuhan nasabah harus menggunakan produk mudharabah atau musyarakah, bagi hasil yang diberikan bank kepada nasabah harus lebih besar dibandingkan bunga dari bank konvensional, sehingga bagi hasil pembiayaan harus lebih kecil dari bunga. Oleh karena itu, apabila bank syariah ingin mengembangkan dirinya dan mendapat kepercayaan dari masyarakat, maka bank syariah harus melakukan penataan dan perbaikan di berbagai aspek, yaitu:

1) Kuantitas dan kualitas keberadaan bank syariah.

2) Manajemen portofolio bank syariah, di mana portofolio pembiayaan perbankan syariah sudah saatnya tidak lagi mengedepankan produk jual beli, namun harus mulai bergeser ke produk syirkah.

3) Kesiapan manajemen kelembagaan, terutama tentang fasilitas operasional bank syariah yang berupa layanan yang serba mudah.

4) Kesiapan persepsi dan perilaku masyarakat terhadap bank syariah. ${ }^{20}$

${ }^{20}$ M. Syafi'i Antonio, dkk, Bank Syariah, Analisis Kekuatan, Peluang, Kelemahan dan Ancaman, (Yogyakarta: Ekonisia, 2006), h. 173. 


\section{B.6. Perbedaan serta Persamaan Perbankan Konvensional dan Perbankan Syariah}

Terdapat persamaan antara perbankan konvensional dan perbankan syariah, di antaranya yaitu pada akad perjanjiannya. Konstruksi hukum pembiayaan mudharabah dan musyarakah yang berdasarkan pada hubungan perniagaan syirkah ini memiliki kesamaan dengan perjanjian persekutuan perdata (perseroan atau maatschap). Perseroan adalah suatu persetujuan di mana dua orang atau lebih mengikatkan diri untuk memberikan sesuatu ke dalam persetujuan dengan manksud untuk membagi keuntungan. Jadi konsepnya, para pihak melakukan usaha bersama-sama, mendapat bagian keuntungan dan kerugian ditanggung bersama.

Namun, dalam hal pembagian keuntungannya terdapat perbedaan. Dalam konvensional, pembagian keuntungan memang diserahkan kepada para pihak, akan tetapi jika hal tersebut tidak diatur dalam perjanjian, maka pembagian itu dilakukan secara proporsional. Di mana pihak yang hanya memasukkan tenaga atau skillnya mendapat bagian yang sama dengan pihak yang memasukkan modal (uang) yang paling sedikit. Berbeda dengan pembagian keuntungan dalam syariah, nasabah sebagai entrepreneur yang memasukkan modal berupa tenaga atau keahliannya mendapat bagian yang lebih besar dari pada bank yang memasukkan modal berupa uang $100 \%$. Dari sini dapat dilihat, bahwa syariah lebih menghargai aspek kemanusiaan yang berupa tenaga kerja, skill, kualitas SDM, dan lain sebagainya.

Terdapat perbedaan mendasar antara sistem konvensional dan sistem syariah dalam bisnis perbankan. Perbedaan yang paling mendasar adalah sistem bunga dalam perbankan konvensional, sedangkan dalam perbankan syariah digunakan sistem bagi hasil. Selanjutnya, perbankan syariah dan perbankan konvensional juga memiliki perbedaan dari segi fungsi. Bank syariah dalam sistem syariah, di samping sebagai badan usaha yang memiliki tujuan memperoleh laba atau keuntungan, juga memiliki fungsi dan peran sebagai badan sosial yang harus memperhatikan kondisi perekonomian masyarakat, seperti adanya produk qardh al-hasan yang telah dijelaskan sebelumnya.

\begin{tabular}{|c|c|c|c|c|}
\hline \multirow{2}{*}{ No. } & \multirow{2}{*}{ Aspek } & \multirow{2}{*}{ Persamaan } & \multicolumn{2}{|c|}{ Perbedaan } \\
\hline & & & Konvensional & Syari'ah \\
\hline 1. & $\begin{array}{c}\text { Akad } \\
\text { Perjanjian }\end{array}$ & $\begin{array}{l}\text { Mudharabah dan } \\
\text { musyarakah dalam } \\
\text { syariah sama dengan } \\
\text { prinsip perseroan } \\
\text { dalam konvensional, } \\
\text { di mana para pihak } \\
\text { bekerjasama, sama- } \\
\text { sama memberikan } \\
\text { masukan modal, } \\
\text { mendapat bagian } \\
\text { keuntungan dan } \\
\text { menanggung } \\
\text { kerugian bersama }\end{array}$ & $\begin{array}{l}\text { Dalam hal } \\
\text { bagian } \\
\text { keuntungan } \\
\text { tidak diatur di } \\
\text { perjanjian, } \\
\text { maka pihak } \\
\text { yang hanya } \\
\text { bermodal usaha } \\
\text { atau tenaga } \\
\text { mendapat } \\
\text { bagian yang } \\
\text { sama dengan } \\
\text { pihak yang }\end{array}$ & $\begin{array}{l}\text { Pihak yang } \\
\text { bermodal } \\
\text { tenaga } \\
\text { (nasabah) } \\
\text { justru } \\
\text { mendapat } \\
\text { bagian yang } \\
\text { lebih banyak } \\
\text { dari pada } \\
\text { bank yang } \\
\text { bermodal } \\
\text { uang } 100 \%\end{array}$ \\
\hline
\end{tabular}




\begin{tabular}{|c|c|c|c|c|}
\hline & & & $\begin{array}{l}\text { bermodal uang } \\
\text { paling sedikit }\end{array}$ & \\
\hline 2. & $\begin{array}{c}\text { Sistem bunga } \\
\text { atau bagi } \\
\text { hasil }\end{array}$ & $\begin{array}{l}\text { Baik bunga ataupun } \\
\text { imbalan, keduanya } \\
\text { sama-sama kontra } \\
\text { prestasi yang harus } \\
\text { diberikan nasabah } \\
\text { kepada bank atas } \\
\text { fasilitas yang } \\
\text { disediakan bank. }\end{array}$ & $\begin{array}{l}\text { Prosentase telah } \\
\text { ditetapkan } \\
\text { sebelumnya } \\
\text { tanpa melihat } \\
\text { apakah } \\
\text { nantinya } \\
\text { debitur akan } \\
\text { untung atau } \\
\text { rugi. Yang jelas, } \\
\text { pihak bank } \\
\text { tetap mendapat } \\
\text { pengembalian } \\
\text { pokok } \\
\text { pinjaman } \\
\text { beserta } \\
\text { bunganya, } \\
\text { bahkan dalam } \\
\text { hal nasabah } \\
\text { bangkrut, dia } \\
\text { tetap dibebani } \\
\text { dengan bunga } \\
\text { berbunga yang } \\
\text { terus } \\
\text { membengkak. }\end{array}$ & $\begin{array}{l}\text { Sebagai } \\
\text { mitra usaha, } \\
\text { bersama- } \\
\text { sama } \\
\text { mendapat } \\
\text { keuntungan } \\
\text { jika } \\
\text { usahanya } \\
\text { berhasil, dan } \\
\text { sama-sama } \\
\text { menanggung } \\
\text { kerugian jika } \\
\text { tidak } \\
\text { berhasil. }\end{array}$ \\
\hline 3. & Fungsi & $\begin{array}{l}\text { Pengumpul dan } \\
\text { penyalur dana }\end{array}$ & $\begin{array}{l}\text { Dengan adanya } \\
\text { system bunga, } \\
\text { bank terkesan } \\
\text { hanya } \\
\text { mementingkan } \\
\text { laba atau } \\
\text { keuntungan } \\
\text { yang akan } \\
\text { diperolehnya }\end{array}$ & $\begin{array}{l}\text { Di samping } \\
\text { sebagai } \\
\text { badan usaha } \\
\text { yang } \\
\text { memiliki } \\
\text { tujuan } \\
\text { memperoleh } \\
\text { laba atau } \\
\text { keuntungan, } \\
\text { juga } \\
\text { memiliki } \\
\text { fungsi dan } \\
\text { peran } \\
\text { sebagai } \\
\text { badan sosial } \\
\text { yang harus } \\
\text { memperhati } \\
\text { kan kondisi } \\
\text { perekonomia } \\
\text { n } \\
\text { masyarakat. }\end{array}$ \\
\hline
\end{tabular}




\begin{tabular}{|c|c|l|l|l|}
\hline 4. & $\begin{array}{c}\text { Lembaga } \\
\text { penyelesai } \\
\text { sengketa }\end{array}$ & $\begin{array}{l}\text { Terdapat aturan dan } \\
\text { lembaga yang akan } \\
\text { menyelesaikan } \\
\text { sengketa yang terjadi }\end{array}$ & $\begin{array}{l}\text { Diselesaikan di } \\
\text { Pengadilan } \\
\text { Negeri sesuai } \\
\text { dengan }\end{array}$ & $\begin{array}{l}\text { Sesuai tata } \\
\text { cara dan } \\
\text { hukum } \\
\text { materi } \\
\text { syariah yang } \\
\text { diatur oleh } \\
\text { BAMUI }\end{array}$ \\
\hline
\end{tabular}

Selanjutnya, perbedaan mengenai system bunga konvensional dan system bagi hasil yang diterapkan oleh perbankan syariah di antaranya yaitu, dalam sistem bunga pada perbankan konvensional, bunga sudah ditentukan besarnya terlebih dahulu oleh bank tanpa memperhitungkan apakah nasabah akan mendapat keuntungan atau tidak. Selain itu, besaran bunganya juga tetap, entah itu nasabah sudah mendapat keuntungan atau malah mengalami kerugian, yang pasti nasabah harus mengembalikan kredit tersebut berupa pinjaman pokok dan bunga dengan jumlah yang sudah ditentukan oleh bank sebelumnya. ${ }^{21}$

Hal ini berbeda dengan sistem bagi hasil yang diterapkan dalam perbankan syariah. Dalam system bagi hasil, besarnya nisbah ditentukan setelah usaha itu dilakukan, yaitu setelah diketahui berapa keuntungan yang didapat. Di awal transaksi hanya ditentukan berapa presentase masing-masing pihak (bank dan nasabah) dalam mendapatkan nisbah tersebut, jadi besaran nisbah berubah sesuai dengan keuntungan yang diperoleh dari sebuah usaha.

Perbedaan-perbedaan dari segi sistem di antara keduanya menyangkut masalah dasar perjanjian, dasar perhitungan imbalan, kewajiban pembayaran imbalan, persyaratan jaminan serta pandangan masing-masing system terhadap system lainnya. Perbedaan antara keduanya dapat dilihat dalam tabel berikut:

\begin{tabular}{|c|l|l|l|}
\hline No. & \multicolumn{1}{|c|}{$\begin{array}{c}\text { Pokok-Pokok } \\
\text { Perbedaan }\end{array}$} & \multicolumn{1}{|c|}{ Bank Konvensional } & \multicolumn{1}{|c|}{ Bank Syariah } \\
\hline 1. & $\begin{array}{l}\text { Dasar perjanjian } \\
\text { penentu bunga } \\
\text { atau imbalan }\end{array}$ & $\begin{array}{l}\text { Tidak berdasarkan } \\
\text { keuntungan atau kerugian }\end{array}$ & $\begin{array}{l}\text { Berdasarkan } \\
\text { keuntungan atau } \\
\text { kerugian }\end{array}$ \\
\hline 2. & $\begin{array}{l}\text { Dasar } \\
\text { perhitungan } \\
\text { bunga atau } \\
\text { imbalan }\end{array}$ & $\begin{array}{l}\text { Presentase tertentu dari } \\
\text { total dana yang } \\
\text { dipinjamkan pada } \\
\text { nasabah }\end{array}$ & $\begin{array}{l}\text { Besarnya nisbah bagi } \\
\text { hasil didasarkan atas } \\
\text { jumlah keuntungan } \\
\text { yang diperoleh }\end{array}$ \\
\hline 3. & $\begin{array}{l}\text { Kewajiban } \\
\text { pembayaran } \\
\text { bunga }\end{array}$ & $\begin{array}{l}\text { Harus terus dilakukan } \\
\text { meskipun usaha nasabah } \\
\text { rugi. Besarnya } \\
\text { pembayaran bunga tetap } \\
\text { meskipun keuntungan } \\
\text { nasabah lebih besar }\end{array}$ & $\begin{array}{l}\text { Dilakukan jika } \\
\text { nasabah untung, } \\
\text { kerugian ditanggung } \\
\text { Bersama. Besarnya } \\
\text { imbalan berubah } \\
\text { sesuai keuntungan. }\end{array}$ \\
\hline 4. & $\begin{array}{l}\text { Perupa barang atau harta } \\
\text { jaminan } \\
\text { pembianaban }\end{array}$ & Tidak mutlak \\
\hline
\end{tabular}

${ }^{21}$ Evy Septiana dan Nurul Mahmudah, “Implementasi Jual Beli Dalam Perikatan Syari'ah Dan Konvensional," Tapis: Jurnal Penelitian Ilmiah, Vol.2, No.2, Desember 2018, h. 16. 


\begin{tabular}{|c|l|l|l|}
\hline 5. & $\begin{array}{l}\text { Objek } \\
\text { pembiayaan }\end{array}$ & $\begin{array}{l}\text { Jenis usaha tidak } \\
\text { dibedakan asal memenuhi } \\
\text { persyaratan }\end{array}$ & $\begin{array}{l}\text { Jenis uasaha yang } \\
\text { dibiayai harus sesuai } \\
\text { syariah }\end{array}$ \\
\hline
\end{tabular}

Sedangkan perbedaan prinsip antara sistem bunga dalam perbankan kovensional dengan sistem bagi hasil dalam perbankan syariah, adalah pada sistem bunga: penentuan bunga dibuat sewaktu perjanjian tanpa didasarkan pada untung dan rugi dapat dilihat secara jelas dalam tabel berikut:

\begin{tabular}{|c|c|c|c|}
\hline No. & Pokok-Pokok Perbedaan & Sistem Bunga & Sistem Bagi Hasil \\
\hline 1. & Penentu besarnya hasil & $\begin{array}{c}\text { Sebelum kegiatan } \\
\text { usaha dilakukan }\end{array}$ & $\begin{array}{c}\text { Sesudah kegiatan } \\
\text { usaha dilakukan }\end{array}$ \\
\hline 2. & $\begin{array}{c}\text { Yang ditentukan } \\
\text { sebelumnya }\end{array}$ & $\begin{array}{c}\text { Besarnya bunga } \\
\text { atau nilai hasil }\end{array}$ & $\begin{array}{c}\text { Kesepakatan porsi atau } \\
\text { bagian masing-masing } \\
\text { pihak }\end{array}$ \\
\hline 3. & Jika terjadi kerugian & $\begin{array}{c}\text { Ditanggung oleh } \\
\text { satu pihak saja } \\
\text { Dari dana yang } \\
\text { diserahkan, bersifat } \\
\text { fixed }\end{array}$ & $\begin{array}{c}\text { Ditanggung kedua } \\
\text { belah pihak }\end{array}$ \\
\hline 4. & Penghitungan & $\begin{array}{c}\text { Dari keuntungan yang } \\
\text { akan diperoleh }\end{array}$ \\
\hline
\end{tabular}

Selanjutnya, persamaan dan perbedaan antara perbankan konvensional dan perbankan syariah dari sisi potensi atau keunggulan, kelemahan, peluang, dan ancaman implikasi bagi masing-masing dapat dilihat dalam tabel berikut:

\begin{tabular}{|c|l|l|l|}
\hline \multirow{2}{*}{ No. } & \multicolumn{1}{|c|}{ Aspek } & \multicolumn{2}{|c|}{ Perbedaan } \\
\cline { 3 - 4 } & & \multicolumn{1}{|c|}{ Konvensional } & \multicolumn{1}{c|}{ Syari'ah } \\
\hline 1. & $\begin{array}{l}\text { Potensi atau } \\
\text { Keunggulan }\end{array}$ & $\begin{array}{l}\text { Dikenal masyarakat, } \\
\text { memiliki akses luas, } \\
\text { dan payung } \\
\text { hukumnya memadai }\end{array}$ & $\begin{array}{l}\text { Dijalankan dengan } \\
\text { prinsip-prinsip ekonomi } \\
\text { Islam, bebas bunga, dan } \\
\text { memiliki fungsi sosial. }\end{array}$ \\
\hline 2. & Kelemahan & Sistem bunga & $\begin{array}{l}\text { Perpajakan, manajemen } \\
\text { SDM, jaringannya } \\
\text { kurang luas, dan belum } \\
\text { terlalu dikenal } \\
\text { masyarakat. }\end{array}$ \\
\hline 3. & Peluang & $\begin{array}{l}\text { Dengan adanya } \\
\text { peraturan yang } \\
\text { memadai, bank dapat } \\
\text { bergerak lebih 'lincah' } \\
\text { dengan membuat } \\
\text { produk-produk baru } \\
\text { atau memperluas } \\
\text { jaringannya, dan } \\
\text { keberadaannya yang } \\
\text { telah akrab dengan }\end{array}$ & $\begin{array}{l}\text { Dengan penerapan } \\
\text { system bagi hasil yang } \\
\text { sempurna, maka bank } \\
\text { syariah dapat bersaing } \\
\text { dengan bank } \\
\text { konvensional. }\end{array}$ \\
\hline
\end{tabular}




\begin{tabular}{|c|c|c|c|}
\hline & & $\begin{array}{l}\text { masyarakat dapat } \\
\text { menarik simpati serta } \\
\text { kepercayaan } \\
\text { masyarakat untuk } \\
\text { menggunakan jasa } \\
\text { perbankan } \\
\text { konvensional. }\end{array}$ & \\
\hline 4. & Ancaman & $\begin{array}{l}\text { Penerapan system } \\
\text { bunga bank } \\
\text { dikhawatirkan akan } \\
\text { kembali menjadi } \\
\text { kendala bagi } \\
\text { kelangsungan bank } \\
\text { itu sendiri, } \\
\text { sebagaimana yang } \\
\text { terjadi ketika krisis } \\
\text { moneter dulu. }\end{array}$ & $\begin{array}{l}\text { System yang ideal tapi } \\
\text { tidak diimbangi dengan } \\
\text { praktek di lapangan. } \\
\text { Yaitu hanya dengan } \\
\text { menerapkan system } \\
\text { murabahah, sedangkan } \\
\text { mudharabah dan } \\
\text { musyarakah tidak } \\
\text { diterapkan. }\end{array}$ \\
\hline
\end{tabular}

\section{B.7. Ketercampuran Sistem Syariah dan Konvensional dalam Sebuah Lembaga} Perbankan

Setelah kita melihat keunggulan dan kelemahan dari masing-masing perbankan, baik konvensional maupun syariah, maka selanjutnya kita akan membahas tentang percampuran sistem-sistem tersebut dalam sebuah bank. Apakah percampuran sistem tersebut mempunyai keunggulan sehingga dapat menciptakan peluang yang luar biasa bagi perkembangan perbankan, atau malah mempunyai kelemahan-kelemahan yang dapat mengancam perkembangan perbankan itu sendiri.

Salah satu keunggulan yang dapat dilihat dari tercampurnya sistem ini adalah dari segi kemudahan aksesnya. Di mana unit-unit dari perbankan konvensional itu tersebar di seluruh daerah, sehingga memudahkan nasabah untuk mengaksesnya. Misalnya, dalam hal perbankan konvensional membuka cabang berupa bank syariah, sedangkan kantor cabang bank syariah tersebut berada di perkotaan, sehingga nasabah yang berasal dari pedesaan akan kesulitan untuk mengaksesnya. Namun, hal ini dapat teratasi dengan adanya perbankan konvensional yang ada di pedesaan. Bank BRI misalnya, seperti yang kita ketahui bahwa bank BRI tersebar luas hampir di seluruh pelosok Indonesia. Ketika BRI membuka cabang berupa BRI Syariah dan kantor dari BRI Syariah itu berlokasi di perkotaan, maka nasabah BRI Syariah yang ada di pedesaan bisa memanfaatkan kantor BRI konvensional yang berada di desa tersebut, begitu juga dengan peyanan ATM-nya.

Ketika system syariah dan konvensional digabungkan, maka kesulitannya adalah dalam hal Sumber Daya Manusianya (SDM). SDM yang benar-benar memahami tentang system syariah dalam sebuah perbankan masih relative sedikit, hal ini disebabkan karena system syariah itu sendiri masih terbilang baru di Indonesia, sehingga SDM yang berkompeten di bidang tersebut juga belum banyak. Dan sekarang ini, perguruan-perguruan tinggi di Indonesia, baik negeri maupun swasta sedang berlomba-lomba menciptakan lulusan yang nantinya akan mengisi SDM di perbankan syariah. 
Di samping karena sedikitnya SDM yang berkompeten di bidang perbankan syariah, perubahan mindset dari konvensional ke syariah juga menjadi kendala. Terutama bagi perbankan konvensional yang membuka cabang berupa bank syariah, secara tidak langsung pegawai-pegawai yang berada di dalamnya juga berasal dari perbankan konvensional tersebut. Oleh karena itu, diperlukan upaya yang lebih untuk merubah mindset mereka, misalnya melalui pelatihan-pelatihan atau seminar-seminar tentang system syariah dalam perbankan. Dengan demikian, bank syariah tidak hanya sekedar nama atau identik dengan pegawai yang berpakaian menutup aurat, namun mindset dari pegawai serta sistem yang ada di dalamnya juga benar-benar sesuai dengan syariat Islam.

Dengan regulasi yang memadai pada perbankan konvensional dan sistemsistem yang baik (prinsip ekonomi Islam) pada perbankan syariah, apabila keduanya digabungkan maka akan menghasilkan lembaga perbankan yang luar biasa. Dengan tidak adanya system bunga (sebagaimana dalam perbankan syariah), maka perbankan akan terhindar dari krisis moneter sebagaimana yang telah terjadi pada tahun 1997. Dan dengan adanya regulasi yang memadai, maka bank bebas bergerak mengembangkan usahanya, misalnya dengan cara membuat produk-produk baru dan lain sebagainya.

Dengan adanya percampuran sistem konvensional dan syariah, muncullah anggapan dari masyarakat bahwa, baik perbankan konvensional maupun syariah itu sama saja, yang membedakan hanya istilahnya (namanya). Selain itu, hal tersebut juga dapat menurunkan elektabilitas perbankan syariah itu sendiri karena telah dianggap keluar dari koridor syariah Islam. Kalangan masyarakat yang faham akan hukum Islam (dalam hal ini riba) juga akan meninggalkannya, karena menganggap percampuran ini merupakan percampuran baina al-haq wa albathil sehingga kepercayaan mereka terhadap system syariah dalam perbankan pun hilang.

\section{Simpulan}

Disini penulis bisa menyimpulkan Bahwa Eklektisisme hukum perikatan nasional yang dimaksudkan dalam tulisan ini adalah percampuran antara system syariah dan system konvensional dalam sebuah lembaga perbankan. Baik perbankan konvensional maupun perbankan syariah mempunyai potensi atau keunggulan, kelemahan, peluang serta ancaman bagi perkembangan masingmasing. Yang kesemuanya itu saling berhubungan satu sama lain. Persamaan antara perbankan konvensional dan perbankan syariah dapat dilihat dari sisi akad perjanjiannya, sedangkan perbedaannya dapat dilihat dari berbagai sisi, yaitu system yang digunakan, fungsinya, serta lembaga penyelesai sengketa. Percampuran system syariah dan konvensional dalam sebuah lembaga perbankan mempunyai sisi positif dan negative. Sisi positifnya dapat dilihat dari segi regulasi yang mengaturnya dan juga kemudahan akses dari perbankan itu sendiri. Sedangkan sisi negatifnya dapat dilihat pada menurunnya bahkan menghilangnya kepercayaan masyarakat akan system syariah yang ada pada sebuah perbankan, karena dengan dicampurnya kedua system tersebut maka perbankan konvensional dan syariah itu sama saja, hanya berbeda Namanya. 


\section{Referensi:}

Qodri Azizy, Hukum Nasional: Eklektisisme Hukum Islam dan Hukum Umum, Jakarta: TERAJU, 2004.

Wikipedia: Ensiklopedia Bebas, Eklektisisme, dalam https://id.m.wikipedia.org/wiki/Eklektisisme, diakses pada tanggal 3 Mei 2016.

Kasmir, Dasar-Dasar Perbankan, Jakarta: PT Raja Grafindo Persada, 2006.

Amir Machmud dan Rukmana, Bank Syariah: Teori, Kebijakan, dan Studi Empiris di Indonesia, Jakarta: Erlangga, 2010.

Eka Widia, Risk Sharing vs Risk Transfer, dalam http://sebishariainsurance.blogspot.co.id/2013/04/risk-sharing-vs-risktransfer_26.html?m=l, diakses pada tanggal 6 Mei 2016.

M.Sulhan dan Ely Siswanto, Manajemen Bank Konvensional dan Syariah, Malang: UIN Malang Press, 2008.

Yusuf Qardhawi, Norma dan Etika Ekonomi Islam, Jakarta: Gema Insani Press, 1997.

Neni Sri Imaniyati, Hukum Ekonomi dan Ekonomi Islam, Bandung: Mandar Maju, 2002.

Muhammad, Sistem dan Prosedur Operasional Bank Syariah, Yogyakarta: UII Press, 2000.

Muhammad Syafi'I Antonio, Bank Syariah dari Teori ke Praktek, Jakarta: Gema Insani Press, 2001.

Abdur Rahman Adi Saputera, "Penyelesaian Sengketa Ekonomi Syariah di Indonesia," Nizham Journal of Islamic Studies, Vol.7, No.01, Juli 2019.

M.Syafi'i Antonio, dkk, Bank Syariah, Analisis Kekuatan, Peluang, Kelemahan dan Ancaman, Yogyakarta: Ekonisia, 2006.

Evy Septiana dan Nurul Mahmudah, "Implementasi Jual Beli Dalam Perikatan Syari'ah dan Konvensional," Tapis: Jurnal Penelitian Ilmiah, Vol.2, No.2, Desember 2016. 